\section{ELLI0TT}

PriceBd. "AFRONAUTICAL NAVGATION" Price ' By Commander Robert A. Newton, R.N.

\section{ENGINE REVOLUTION} INDICATORS INDIS ${ }^{\mathrm{R}} \mathrm{N}^{\mathrm{E}} \mathrm{EABLE}$

Fitted to the principal flying machines

i/Nffvp n n st c 36, Leicester Square, \& Cen ${ }^{\mathrm{r}} \mathbf{E} \mathbf{L} \mathbf{L} \mathbf{O}$ T T B R O S, , tury Works, Lewisham Telegrams: "Elliottize, London." Telephones: Gerrard 1640,1641

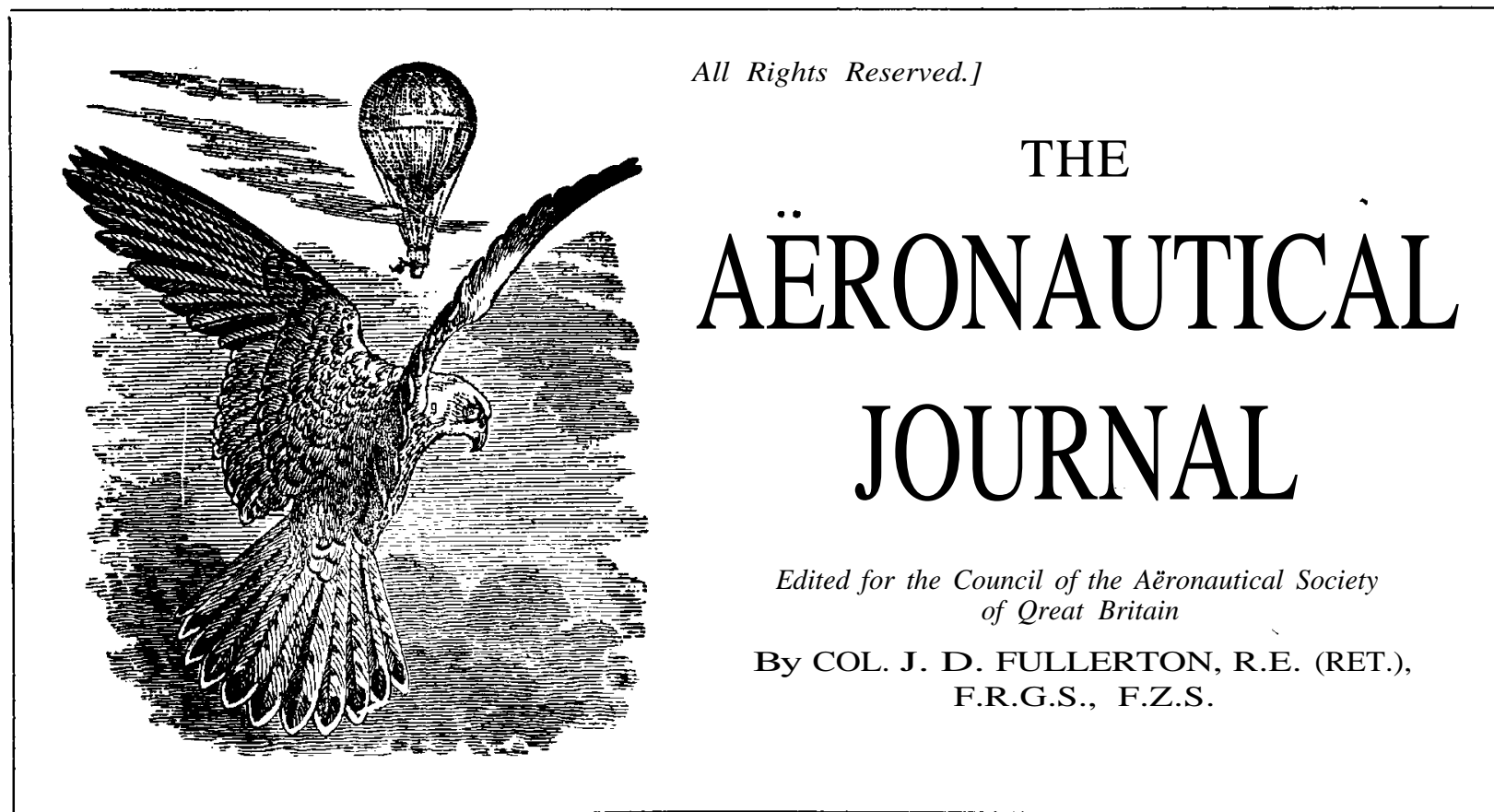

No. 52

combine lightness with strength. All interested in aviation should learn all about them. YOUR enquiry will be esteemed

\title{
Handley Page,
}

11 The House for all things pertaining to aviation "

London Office:

72, Victoria St., S.W.
Works:

Creekmouth, Barking
West of England :

Bridgwater Motor Co., Bridgwater 
Telephone No. P.O. Kingston lisa

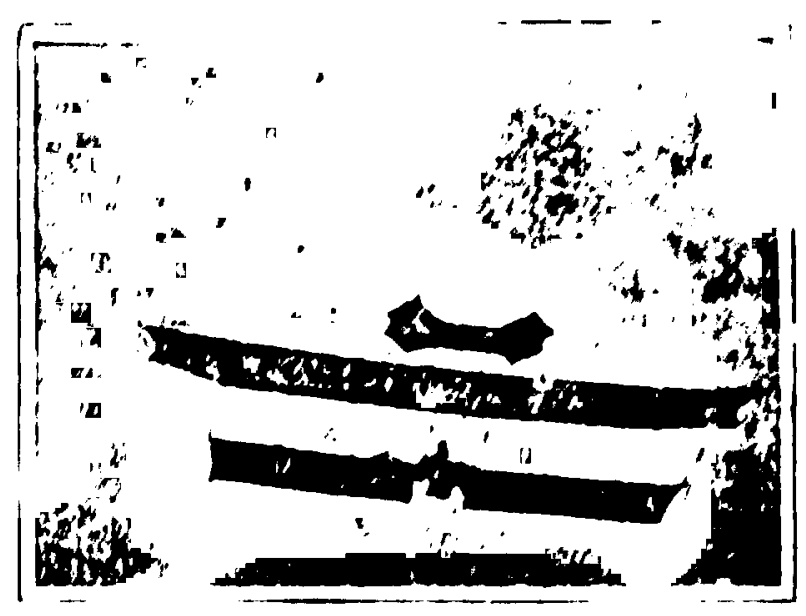

TeUtframe • Flyere, Kingston on Th.mM."

T. W. K. CLARKE \& GO. Aeronautical Engineers AEROPLANES GLIDERS FINEST QUALITY BUILT UP WOOD PROPELLERS FABRICS \&C.

Gliders from $£ 40$

Aeroplanes complete from $£ 380$

Crown Works, High Street Kingston-on-Thames

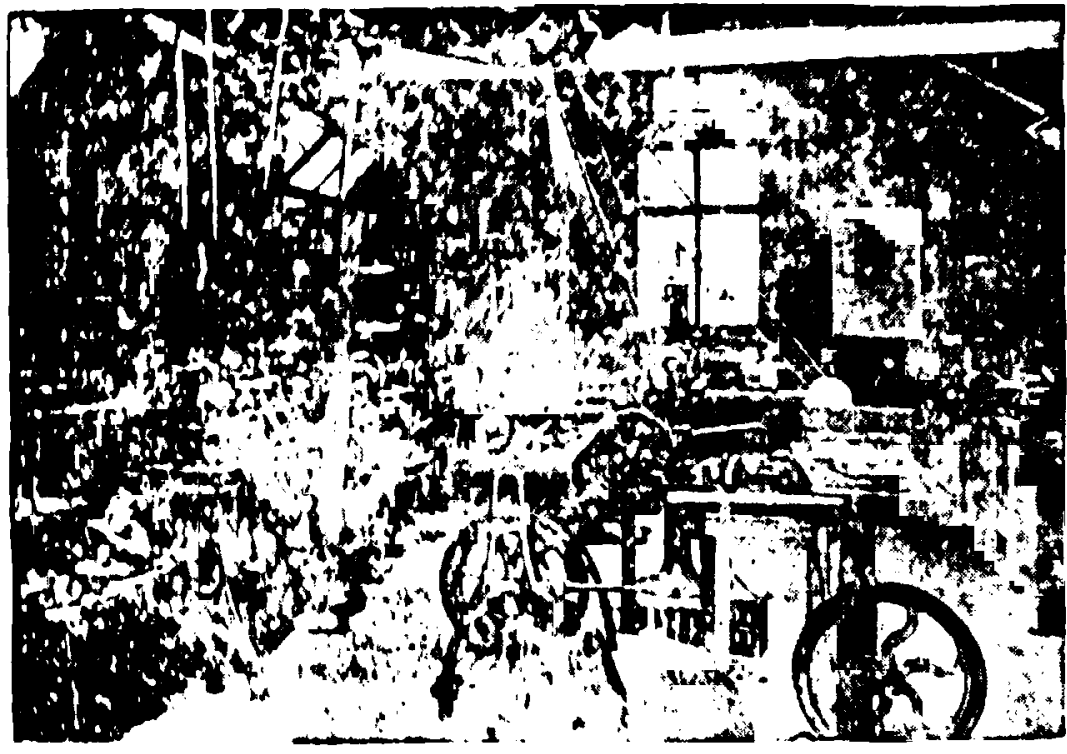

H. W. LANE,

Model Engineer.

26. PENGE ROAD, SOUTH NORWOOD LONOON, S.E.

Aeroplanes and Models constructed. Inventors' experiments conducted in strict confidence-

Well.equipped private workrooms available for Clients personal use.

Wood rodi and sections to any lire and shape.

$M$ agnail urn or steel joining plates, wire tightening screws, magnallu-n screws and nuts, and other special fittings made to order.

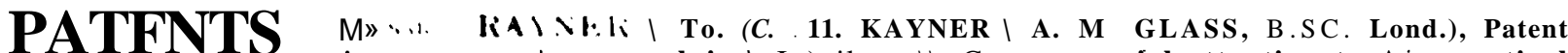

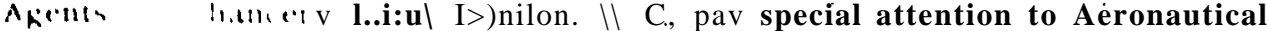

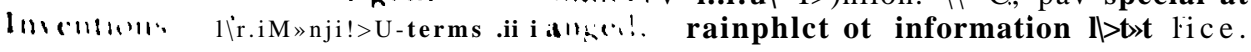

\section{E. S. B. MACKENZIE-HUGHES, AIIROIAL"riCAL El(J/IEER,} 14, Howlck Plaoe, Victoria St., Westminster, London, S.W. ii-ipMo'u -533J Westminster

Designing and Draughting undertaken. Drawings prepared to requirements of Inventors, Also Patent Drawings and Specifications drawn up.

Works-A. W. SMITH A CO., London Road, BarMn*. E. Telephone N : y. . K.^t Ham.

MODELS AND FULL SIZE MACHINES CONSTRUCTED TO ANY DESIGN

All Work undertaken and carried out strictly in privat* for each Client Pi;k>ONAL ASSISTANCI: OIMN IF REQI IRED

THREC YEARS' GOOD E $X$ PE If IK NC $£$ IN THIS CLASS OF WORK Any Aeronautical Rapaire un «iertak «n 
THE HUTCHINSON Special Cloths - FOR -

BALLOONS, AEROPLANES AND DIRIGIBLES

have been subjected to severe trials with the greatest success

Extra Light Fabric5, of Ureat Strength, for AEROPLANE CONSTRUCTION CONTRACTORS TO THE FRENCH (10VERNMENT

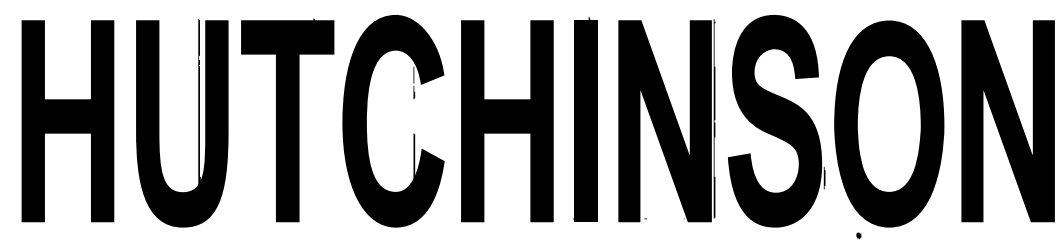

\section{IMPORTANT/}

The envelope of the first Dirigible Airship ordered for England, and built by the eminent firm of Lebaudy Fr\&res, has been constructed of HUTCHINSON BALLOON CLOTH which has passed some very severe Government tests in France

Samples, Price Lists, and Full Particulars on application

\section{THEHUTCHINSON COMPANY,} 70, BA8IN6HALL 8TREET, LONDON, E.C. 


\section{AEROPLANES Actually in Stock}

\section{G. GRAHAME-WHITE \& $\mathrm{CO}_{0}, \mathrm{LTD}$.}

positively guarantee delivery of undermentioned aëroplanes against substantial cash penalty, and give series number of any machine offered

LIST OF AËROPLANES WITH PRICES ACCORDING TO DATES OF DELIVERY ON APPLICATION

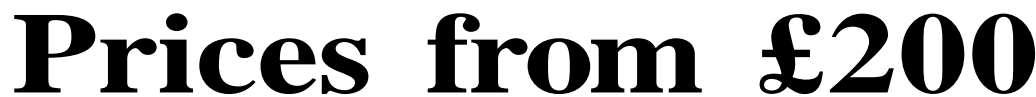

FREE TUITION given with all aëroplanes ordered from us, and one mile guaranteed flight on delivery

SANTOS-DUMONT，30-h.p. 2-cyl. DARRACQ, water-cooled-Type, "Dragon

Fly" MONOPLANE

BLERIOT, 25-h.p. 3-cyl. ANZANI, air-cooled-Type, XI. Calais-Dover MONOPLANE BLERIOT, 30-h.p. 2-cyl. DARRACQ, water-cooled-Type, XI. Calais-Dover MONOPLANE

BLERIOT, 80-h.p. 8-cyl. E.N.V., water-cooled-Type, XII. long-distance or 3-seated MONOPLANE

ANTOINETTE, 50-h.p. 8-cyl. ANTOINETTE, water-cooled-Type, Latham MONOPLANE

ANTOINETTE, 100-h.p. 16-cyl. ANTOINETTE, water-cooled, 2-seated, 60 miles per hour, MONOPLANE

FARMAN, VOISIN, WRIGHT BIPLANES Fitted with any motor to purchaser's choice

\section{Special AËRO-MOTORS for Immediate Delivery ANZANI ANTOINETTE MORS

\author{
E.N.V. \\ GREEN
} VIVINUS \\ GNOME RENAULT CURTISS}

We supply all necessary materials for building Ä̈ROPLANES, and have made arrangements to let suitable workshops to intending constructors

FULLEST PARTICULARS ON APPLICATION

\section{GRAHAME-WHITE \& Co., LTD.} 1, ALBEMARLE STREET, PICCADILLY, LONDON, W. 